\title{
Strict and Comprehensive Tobacco Control Policy is Needed: A Qualitative Study Exploring How People Responding a New Policy of Pictorial Health Warning on Cigarette Package in Indonesia
}

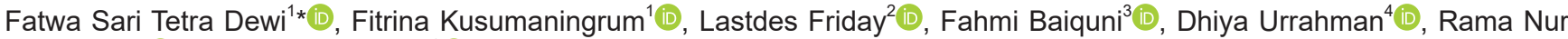 \\ Kurniawan $^{5}$ iD, Rendra Widyatama ${ }^{6}$ iD \\ ${ }^{1}$ Department of Biostatistics, Epidemiology and Population Health, Faculty of Medicine, Public Health and Nursing, Universitas \\ Gadjah Mada, Yogyakarta, Indonesia; ${ }^{2}$ Master of Public Health, Faculty of Medicine, Public Health and Nursing, Universitas \\ Gadjah Mada, Yogyakarta, Indonesia; ${ }^{3}$ Applied Bachelor Program of Health Promotion, Health Polytechnic Karya Husada \\ Yogyakarta, Indonesia; ${ }^{4}$ Department of Health Promotion, Faculty of Public Health, Universitas Pancasakti, Makassar, \\ Indonesia; ${ }^{5}$ Department of Communication, Universitas Ahmad Dahlan, Yogyakarta, Indonesia; ${ }^{6}$ Károly Ihrig Doctoral School \\ of Management and Business, University of Debrecen, Debrecen, Hungary
}

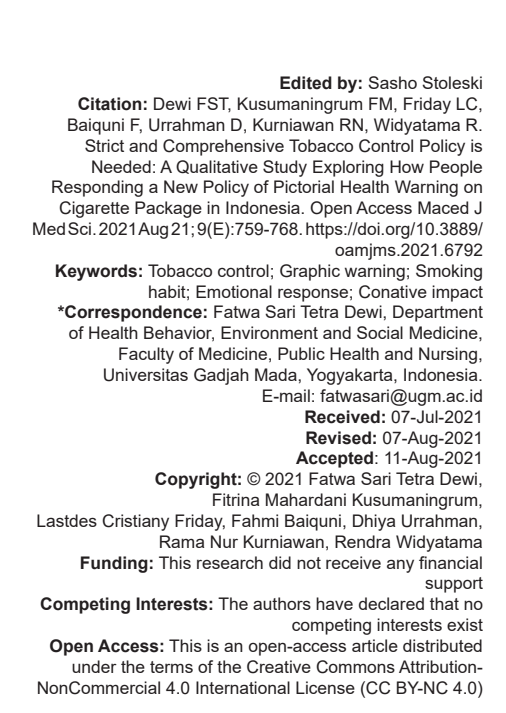

Abstract

BACKGROUND: Little is known about the process on how smoker and nonsmoker responses to a Pictorial Health Warning (PHW) which is important for policy improvement.

AIM: We aim to explore the nature of the reaction and the extent of impact of the PHW implementation on smoking habit in Indonesia.

METHODS: We collected the data among adult aged 18+ years in Sleman District, Yogyakarta, Indonesia, involving 45 informants in in-depth interviews and 22 informants in four Focus Group Discussions, selected using the maximum variation sampling according to smoking status and area of residence. We discussed with respondents about the meaning of the PHWs, how they felt when seeing the PHWs, how those feelings emerged when seeing the PHWs, and the impact of seeing the PHWs. We analyzed the data using the content analysis.

RESULTS: PHWs raised the intended negative emotional response, that wearing out over time. However, for smokers, the disease threat in the message was less obvious than to defeat smoking addiction. Smokers tried to manage their risk of illness themselves. Among non-smokers, they were more confident in being non-smokers. Both smokers and non-smokers thought that Government is half-hearted in controlling the smoking problem. Smokers were grateful, but non-smokers were sorry for this.

CONCLUSIONS: The application of PHW threatens smokers but does not make them quit smoking because of the fear of defeating cigarette dependence. For non-smokers, they feel more confident to be a smoker-free. Respondents claim the government is not serious about controlling smoking.

\section{Introduction}

Globally, the prevalence of tobacco smoking among aged $15+$ is $21.9 \%$ and Indonesia ranks the seventh highest in the prevalence of tobacco smoking (39.5\% of its population) [1]. Tobacco decreases life expectancy, excluding smoking-related death would increase life expectancy by 2.4 year among men and 1 year among women globally [2].

In 2003, the WHO proposed the implementation of Framework Convention on Tobacco Control (FCTC) to control tobacco globally. The FCTC strategies are summarized in MPOWER emphasize to monitor the smoking epidemic, protect passive smokers, offer help to quit smoking, warn about the dangers of smoking, encourage ban of tobacco advertisements, and raise cigarette taxation [3]. Indonesia is the only country in South-east Asia that has not ratified FCTC [4] but has implemented the MPOWER strategy. Enacted in 2014, The Government of Indonesia requires the inclusion of Pictorial Health Warnings (PHW), there are five versions of PHWs which must be printed on each variant of tobacco packaging equally, covering $40 \%$ of the wide area of the front and back sides [5], [6].

Implementing PHW policy is to remind the dangers of smoking for health, especially for smokers. The effectiveness of the PHW policy among smokers shows varied results. A study in US found the inclusion of PHW in cigarette packaging effectively created a negative emotional response, increased motivation and intention to quit smoking [7], although there are other variables identified to determine the success of quit smoking: Having health problems [8], [9], young age, 
low exposure to cigarette smoke in the environment, knowledge of the dangers of smoking, and advice from health officer [10]. Studies in some Asian countries (Indonesia, Thailand, and India) found that PHW has a limited impact on success to quit smoking among smokers [11], [12], [13], possibly because of the difficulty to quit smoking [13].

The effectiveness of PHW policy implementation on non-smokers also varied. Among non-smokers in several Asia countries (Thailand, Indonesia, Turkey, Qatar, and India), the inclusion of $\mathrm{PHW}$ on cigarette packages found to be effective in preventing the smoking initiation [12], [13]. However, a study in Canada showed that the same policy creates a knowledge gap between smokers and non-smokers, which non-smokers significantly have lower knowledge than smokers about the danger of smoking; the researchers argued those non-smokers might be at risk of start smoking [14].

Although many studies measured the effectiveness of PHW implementation toward smoking habit; however, little is known on the process of how smokers and nonsmokers responding to a $\mathrm{PHW}$ implementation. This understanding is important to improve the implementation of PHW policy to control smoking. This study aims to explore the nature of the reaction and the extent of impact of the PHW implementation on smoking habit among smokers and non-smokers in Indonesia.

\section{Methods}

\section{Study design and location}

A qualitative study using face-to-face semistructured interviews and focus group discussions (FGDs) were selected to achieve the aims of this study. This study was part of a wider mixed-methods study to measure how effective the implementation of $\mathrm{PHW}$ to render people from smoking. Those results reported [15], [16], [17] and published elsewhere. The findings from the qualitative parts of that wider study were important to be comprehensively analyzed and published in this article.

This study is in Sleman District, Special Region of Yogyakarta, in Java Island, Indonesia. The Sleman District covers an area of $574.82 \mathrm{~km}^{2}$, has $1,113,707$ inhabitants (2017) and has $85 \%$ urban areas. This district is an agglomeration area of Yogyakarta City, the capital city of Yogyakarta Province [18]. We selected three subdistricts, two subdistricts were majority urban areas (Depok and Mlati) and one subdistrict was majority rural area (Prambanan) in Sleman District, following the maximum variation sampling to provide rich information on the phenomenon of "how people respond to PHWs" manifest [19]. The selection of three subdistricts as the study location with an expectation could be reflected to broader Jogjakarta province and Indonesia's context with careful considerations.

\section{Respondents and data collection}

Our sample comprises adults aged $18+$ years as the minimum age to purchase or use cigarettes according to the regulation [6]. We selected informants following maximum variation sampling according to smoking status and area of residence, to understand the phenomenon from different perspectives [20]. Although the main target of PHW are for smokers, in Indonesia non-smokers are also exposed to PHW in the tobacco products that is freely displayed on the shelf for selling and $\mathrm{PHW}$ in tobacco advertisements that required to be included for $10 \%$ of advertisements' duration (or $15 \%$ of advertisement's area). We considered informants from different residential areas were likely to respond differently to PHW because of different modernization levels. There were few women informants invited to participate in the interviews to understand how responses to PHW differed according to sex.

The data collection was in June to October 2015, at the beginning of the regulation enforced printing PHW on cigarette packages in June 2014, we believe it was long enough for the respondents to recognize the new warning and short enough to recall how they had been responding to PHW. Each data collection began with an introduction to the study and asked for informed consent, followed with brief questions regarding their smoking status and demographic characteristics before asking questions about the responses on PHW.

We developed the interview guideline based on the Extended Parallel Process Model (EPPM) which explains the perceived threat (of the severity and susceptibility of the disease) and the perceived efficacy (of self-efficacy and response efficacy) contributed the response to a fear appeal warning [21]. After conducting a pilot data collection, we revised the guideline accordingly, and we revised the guideline along the data analysis following the results we found on previous data collection to ensure the depth of exploration. We showed the PHWs in cigarette packs both big and small package (contain 16 and 12 cigarettes), as necessary [5], and asking about the meaning of the PHWs, how they felt when seeing the PHWs, how those feelings emerged when seeing the PHWs, and the impact of seeing the PHWs. We showed the cigarette packages with different PHWs that arranged from the one least provoking negative emotion based on media expert assessment (Figure 1). This arrangement was to avoid opinion distortion, which may have been raised from previous pictures. 

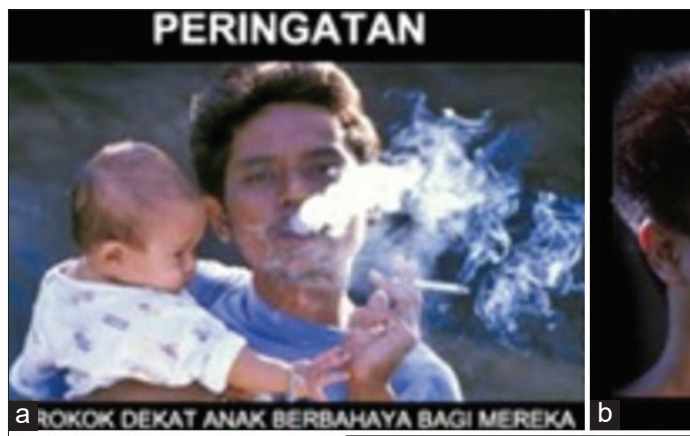

PERINGATAN

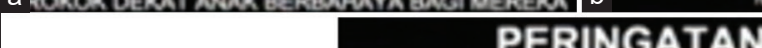

MEROKOK MEMBUNUHMU
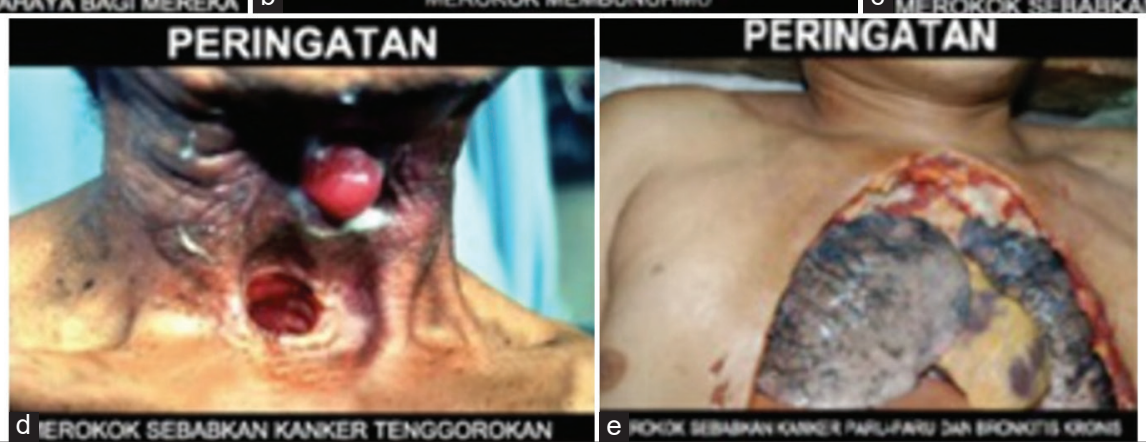

Figure 1: The introduced pictorial health warning. Source: Regulation of the health minister of The republic of Indonesia number 28 of 2013 [5] (a) Pictorial Health Warning (PHW)1 A smoker with child (b) PHW2 A smoker and skulls (c) PHW3 Oral cancer (d) PHW4 Throat cancer (e) PHW5 Lung cancer

\section{Data analysis}

A qualitative content analysis both the manifest or obvious content and latent content that involved interpretation of the text meaning was done [22]. By using the content analysis, we emphasize the importance of the subject and the context under the study, how each informant communicates their opinion in relation with the condition on himself and his surroundings. Constant comparisons applied to understand the opinion between smoker and non-smoker [20].

The $4^{\text {th }}, 5^{\text {th }}$, and $6^{\text {th }}$ authors conducted the interviews which were voice recorded, transcribed, and concealed informant's identity. A research assistant who fluent in Javanese language helped as an interpreter for the $5^{\text {th }}$ and $6^{\text {th }}$ authors during the interviews. Those authors then identified the meaning units, identified the codes, and categorized without considering the EPPM theory [21], under the supervision of the $1^{\text {st }}, 2^{\text {nd }}$, and $7^{\text {th }}$ authors. We used OpenCode 4.03 software to process the analysis [23]. Separately, the $1^{\text {st }}$ and $2^{\text {nd }}$ authors analyzed the data for researcher triangulation. Whenever a different analysis result arose between the two sides, we discussed accordingly to build a new interpretation. We also compared the results of in-depth interviews with FGD as a triangulation of methods.

For the negative case analysis, we search for data that do not confirm the result and explore the clarification to revise the understanding. Further informants were involved for clarification until reached data saturation. For example, it was found a pattern in which smokers were not afraid of the warning images, but few smokers claimed they were afraid and wanted to quit. Further investigation found that the smokers who wanted to quit felt old, not only because of the PHW exposure.

The $1^{\text {st }}$ author is an MD, the $2^{\text {nd }}$ author is a health promotion expert, the $7^{\text {th }}$ authors are a communication expert, they used to conduct qualitative research, the $3^{\text {rd }}$ author is a biostatistics expert. Three students who were pursuing a master of public health involved in this study: The $4^{\text {th }}$ author is a psychologist; the $5^{\text {th }}$ and $6^{\text {th }}$ authors are a public health bachelor. The $1^{\text {st }}, 2^{\text {nd }}$, and $7^{\text {th }}$ authors are fluent in Javanese language and understand the Javanese culture. By having a different expertise background of authors, we attempt to interpret the data from multiple perspectives.

Ethical approval has been provided by the Ethics Committee of Faculty of Medicine, Public Health and Nursing, UGM number KE/FK/609/EC/2015. Permission was given by the local authority and informed consent was granted by each informant before the data collection. The findings are reported following the standards for reporting qualitative research [24].

\section{Results}

The authors conducted 45 in-depth interviews involving 45 informants and 4 FGDs involving 22 informants. The average length of interviews was $26 \mathrm{~min}$ $20 \mathrm{~s}$, and the FGDs were $67 \mathrm{~min} 30 \mathrm{~s}$. Researchers interviewed at the informant's homes or in public areas according to the informants' preferences, whereas the FGDs at the community leaders' home. The characters 
of informants in the in-depth interview and FGD are presented in Table 1.

Table 1: Characteristics of informants participating in the in-depth interview and FGDs

\begin{tabular}{|c|c|c|c|c|}
\hline \multirow[t]{2}{*}{ Characteristics } & \multicolumn{2}{|l|}{ In-depth interview } & \multicolumn{2}{|c|}{ Focus group discussions } \\
\hline & Smoker $(n=20)$ & $\begin{array}{l}\text { Non-smoker } \\
(\mathrm{n}=25)\end{array}$ & Smoker $(n=13)$ & Non-smoker $(n=9)$ \\
\hline \multicolumn{5}{|l|}{ Sex } \\
\hline Man & 18 & 19 & 13 & 9 \\
\hline Woman & 2 & 6 & 0 & 0 \\
\hline \multicolumn{5}{|l|}{ Age group } \\
\hline $18-24$ & 2 & 3 & 2 & 0 \\
\hline $25-44$ & 10 & 15 & 6 & 4 \\
\hline $45-69$ & 8 & 7 & 5 & 5 \\
\hline \multicolumn{5}{|l|}{ Residence } \\
\hline Urban & 9 & 12 & 7 & 4 \\
\hline Rural & 11 & 13 & 6 & 5 \\
\hline
\end{tabular}

Three domains organized our analysis: emotional response, cognitive, and conative, which comprised different categories between smokers and non-smokers. Emotional response refers to what the reaction of feeling that arises after seeing $\mathrm{PHWs}$, while the cognitive domain about PHWs was the thoughts and belief regarding the message. The conative domain of respondents was the impact of PHW on respondents' action. Each category was supported with codes, as shown in Table 2. We present the categories for each domain for smokers and for non-smokers separately.

Table 2: Categories and supporting codes of each domain of smokers and non-smokers

\begin{tabular}{|c|c|c|}
\hline \multirow[t]{2}{*}{ Themes } & \multicolumn{2}{|l|}{ Categories and codes } \\
\hline & Smokers & Non-smokers \\
\hline $\begin{array}{l}\text { Emotional } \\
\text { response }\end{array}$ & $\begin{array}{l}\text { Feel threatened } \\
\text { 1. Worry into get used to: } \\
\text { a. Initially feel worry } \\
\text { b. Covering fear by saying } \\
\text { pity for person on PHW } \\
\text { c. Familiar with PHW } \\
\text { 2. Triggered by the threatening } \\
\text { aspect of the image: loss of } \\
\text { function to death }\end{array}$ & $\begin{array}{l}\text { Feel grateful } \\
\text { 1. Disgusted into get used to: } \\
\text { a. Initially disgusted } \\
\text { b. Sense of relieved but pity for } \\
\text { smokers } \\
\text { c. Familiar with PHW } \\
\text { 2. Triggered by the disgusting aspect of } \\
\text { the image: color, cut }\end{array}$ \\
\hline Cognitive & $\begin{array}{l}\text { Deny } \\
\text { 1. Message content: don't } \\
\text { believe the PHW } \\
\text { 2. Target: Messages are } \\
\text { primarily not for smokers } \\
\text { himself } \\
\text { 3. Aim: just information that } \\
\text { smoking is harmful } \\
\text { 4. Sender: Fortunately, the } \\
\text { government is half-hearted } \\
\text { controlling smoking }\end{array}$ & $\begin{array}{l}\text { Doubt } \\
\text { 1. Content: between believe and not } \\
\text { believe the PHW } \\
\text { 2. Target: Messages are primarily for } \\
\text { smokers } \\
\text { 3. Aim: should be more than just } \\
\text { information } \\
\text { 4. Sender: The government does not } \\
\text { control smoking seriously }\end{array}$ \\
\hline Conative & $\begin{array}{l}\text { Refuse } \\
\text { 1. Avoid the image } \\
\text { 2. Fulfill dependence rather } \\
\text { than fear } \\
\text { 3. Balancing smoking with } \\
\text { healthier habit } \\
\text { 4. Health and sickness are } \\
\text { destiny }\end{array}$ & $\begin{array}{l}\text { Accept } \\
\text { 1. Avoid the image } \\
\text { 2. More confident stay smoke-free } \\
\text { 3. Smoker will not give up }\end{array}$ \\
\hline
\end{tabular}

\section{Smoker}

\section{Emotional response: Feel threatened}

Participants recognized there were new labels on cigarette packages when they bought the cigarette. The label triggering threatened response. Smoker participants generally feel threatened by the PHW show the sickness related to smoking (not the PHW shows a smoker with a child and PHW shows smoker and skulls).
Initially, they feel worried if they experienced sickness similar to the picture, but this worry often covered by expressing as pity for the person whose picture is taken in PHW. The feeling triggered with the aspect of image in PHW interpreted as loss of organ function until death. For example, the participants stated "cannot eat, drink and are difficult to speak" when observing the oral cancer PHW. Different emotional response for the PHW shows a smoker with a child. Although smokers feel indifferent with the PHW, there are smokers who feel sorry because the cigarette smoke is dangerous for children, for example, they stated "yea maybe (the child) can be affected by the father (smoke) maybe... the lung of the child later can be affected." Those who feel sorry were smokers that already sick, old or witnessed relatives who got sick because of smoking. However, those threaten and sorry feelings disappear over time when the participants get used to the PHW (Table 3).

\section{Cognitive: Deny}

Smoker participants questioned the credibility of the messages and further denied the messages on the PHWs. Smoker participants in general denied the credibility of the information on the PHW, except to those smokers who were already sick, old, or witnessed relatives who got sick because of smoking. The denial reflected on their statement "not having an appetite for smoking means unhealthy," meaning that smoking habit is used as a standard for a health condition. They rejected the credibility of the information conveyed on PHW that smoking causes unhealthy conditions. They said that "pictures could be made up" to look threatening.

Smokers recognized that the information in PHW threatening smokers by showing that smoking is an unhealthy habit, but they argued that the information on PHW targeted other people such as experimenting smokers or those non-smokers to deter smoking.

Smokers considered that the government can take decisive action to control smoking, but they were grateful the government did not. They exemplified that other cigarette restriction policies would be more effective than $\mathrm{PHW}$, such as increasing cigarette price policy would make them reduce cigarette consumption. Extremely smokers challenged the government to close cigarette factories would absolutely make them stop smoking. Smokers believe that the government would not dare to do it for the amount of revenue raises from cigarette business (Table 3).

\section{Conative: Refuse}

There was a persistent refusal to quit smoking as the consequence of the information on the PHWs. Smoker participants basically refused to stop their smoking habit. They took various coping mechanisms to avoid warning images, for example, using old packaging, tearing up the image, attaching a sticker on the image and choosing 
Table 3: Categories and example statements of emotional response, cognitive, and conative domains among smokers

\begin{tabular}{|c|c|}
\hline Themes and categories & Example statements \\
\hline \multicolumn{2}{|l|}{$\begin{array}{l}\text { Emotional response } \\
\text { Feel Threatened }\end{array}$} \\
\hline \multicolumn{2}{|l|}{ Feel Threatened } \\
\hline a. Initially feel worry & $\begin{array}{l}\text { "Well, first time, it was a bit horrified, afraid, could it } \\
\text { be like this (this sickness), there was a feeling like } \\
\text { that too." (A boy, } 19 \text { years) }\end{array}$ \\
\hline $\begin{array}{l}\text { b. Covering fear by saying pity } \\
\text { for person on PHW }\end{array}$ & $\begin{array}{l}\text { "Yeah like this is so pity yeah, until like this only } \\
\text { because of smoking, how come the consequences } \\
\text { can be like this (refer to PHW showing throat } \\
\text { cancer)." (A man, } 60 \text { years) }\end{array}$ \\
\hline c. Familiar with PHW & $\begin{array}{l}\text { "Maybe I felt disgusted only at the beginning, things } \\
\text { I never knew then I know for sure. After then huh... } \\
\text { being adapted with the new packaging and it is fine." } \\
\text { (A man, } 28 \text { years) }\end{array}$ \\
\hline $\begin{array}{l}\text { d. Triggered by the threatening } \\
\text { aspect of the image: loss of } \\
\text { function to death }\end{array}$ & $\begin{array}{l}\text { "The mouth... (he) can't eat or drink, right? For } \\
\text { example to speak, (he) can't speak as well, ...yeah." } \\
\text { (A man, } 60 \text { years) }\end{array}$ \\
\hline \multicolumn{2}{|l|}{ Cognitive } \\
\hline \multicolumn{2}{|l|}{ Deny } \\
\hline $\begin{array}{l}\text { a. Message content: don't } \\
\text { believe the PHW }\end{array}$ & $\begin{array}{l}\text { "But, for example, that person (who is sick) wants } \\
\text { to smoke again, the disease disappears, bro, get } \\
\text { cured, get well. Hence, if, for example, likes to } \\
\text { smoke, it means almost cured, like that." (A man, } \\
33 \text { year) } \\
\text { "A picture can be made of any picture (manipulated } \\
\text { related to cigarette). It is a possibility that the picture } \\
\text { is made like this." (A man, } 43 \text { years) }\end{array}$ \\
\hline $\begin{array}{l}\text { b. Target: Messages are } \\
\text { primarily not for smokers } \\
\text { himself }\end{array}$ & $\begin{array}{l}\text { "For me (the target of the picture) for the } \\
\text { beginners ...well they can still be corrected, for } \\
\text { example, teenagers. For beginners, there is still } \\
\text { a chance to reduce the number of cigarettes } \\
\text { consumed." (A man, } 54 \text { year) }\end{array}$ \\
\hline $\begin{array}{l}\text { c. Aim: Just information that } \\
\text { smoking is harmful }\end{array}$ & $\begin{array}{l}\text { "..it looks like the initial goal is indeed good, } \\
\text { maybe...e...smoking is not healthy like that, } \\
\text { these are some examples (of diseases related to } \\
\text { smoking), but well e...to force the smokers I don't } \\
\text { think it works, the smokers still smoking, bro." (A } \\
\text { man, } 47 \text { year) }\end{array}$ \\
\hline $\begin{array}{l}\text { d. Sender: Fortunately, the } \\
\text { government is half-hearted } \\
\text { controlling smoking }\end{array}$ & $\begin{array}{l}\text { "If the government want to be serious...strictly } \\
\text { reduce cigarette production, just control directly at } \\
\text { the factory...but that will also affect (government's) } \\
\text { revenue from cigarettes excise itself." (A man, } 54 \\
\text { years) }\end{array}$ \\
\hline \multicolumn{2}{|r|}{ 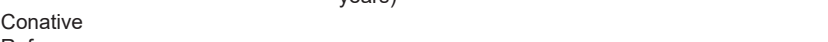 } \\
\hline \multicolumn{2}{|l|}{ Refuse } \\
\hline a. Avoid the image & $\begin{array}{l}\text { "There is a picture that is ...like what is it like this } \\
\text { (showing oral cancer)... if you look at it, it's not } \\
\text { comfortable, usually I will discharged it, tear it, or move } \\
\text { it to other packaging like that." (A man, } 33 \text { years) } \\
\text { "Well, that's how it is....already addicted right...don't } \\
\text { think about pictures" (A man, } 50 \text { year) }\end{array}$ \\
\hline \multirow[t]{2}{*}{ b. PHW doesn't stop smoking } & $\begin{array}{l}\text { "Well, there must be afraid feeling, but when I smoke } \\
\text { it's oke, forget about with smoking, forget it. When } \\
\text { smoking l'm not thinking (the diseases that may } \\
\text { arise)." (A boy, } 19 \text { years) }\end{array}$ \\
\hline & $\begin{array}{l}\text { "That's now A (his relative), yea he is now stop } \\
\text { smoking, he was a heavy smoker before. However, } \\
\text { not anymore right now, yea maybe because of illness } \\
\text { or diseases or what. .f he is suffer (from serious } \\
\text { disease), definitely stop smoking." (A man, } 33 \text { years) }\end{array}$ \\
\hline $\begin{array}{l}\text { c. Balancing smoking with } \\
\text { healthier habit }\end{array}$ & $\begin{array}{l}\text { "Oh yea... that's maybe with a lot of exercise I think } \\
\text { it is okay, perhaps for those who smoke should } \\
\text { balance with a lot of exercise, if he/she doesn't work } \\
\text { as a garden hoes, field hoes, better to exercise a lot, } \\
\text { it's okay.." (A man, } 47 \text { years) }\end{array}$ \\
\hline $\begin{array}{l}\text { d. Health and sickness are } \\
\text { destiny }\end{array}$ & $\begin{array}{l}\text { "But for disease matter, God makes it isn't it? die } \\
\text { and life is determined by Him." (A man, } 60 \text { years) }\end{array}$ \\
\hline
\end{tabular}

the PHW1 and PHW2 packages and many others. Smokers claimed that defeating cigarette addiction was more difficult than controlling the fear of diseases related to smoking. Only informants who were already sick, old or witnessed relatives who got sick because of smoking would claim their willingness to control smoking habit. They suspected some sickness related to smoking habits such as heart disease or coughing.

Respondents who continue smoking try to stay healthy by balancing their smoking habit with other healthy habits according to their belief, such as more physical activity, consume more healthy diet. Furthermore, they tried to "neutralize" the smoke they consume, such as providing time lag for 15 min between eating and smoking, and consumed some white beverages such as milk, soda, and plain water. After taking various efforts to avoid diseases related to smoking, the smoker then tried to make reconciliation with the threat of the diseases by surrendering it to God's destiny. They considered the sick condition as being given a trial by God, as part of destiny determined by God (Table 3).

\section{Non-smoker}

\section{Emotional response: Feel grateful}

Participants recognize there were new label on cigarette packages from the street vendors, stores, their friends, or relatives. The new label triggered a grateful feeling of being a non-smoker. Non-smokers informants initially felt a sense of disgusted finding the new label on the cigarette package. They were relieved that they were not among those might affected with similar diseases, on the other hand, they feel pity for their smoker relatives that might be affected. This uncomfortable feeling gradually decreased when the respondent got used to see the PHW. The disgust feeling triggered by the image, especially on the aspect of color and cut. Nonsmokers concerned the red color of an organ interpreted as wound, white as blister, black as burnt (Table 4).

\section{Cognitive: Doubt}

In general, non-smoker participants questioning the credibility of the messages, because they use to being surrounded by smokers on being daily basis, they might not consider the danger of tobacco. Non-smoker participants doubt the messages on the PHWs. Nonsmoker participants expressed their doubt of, "between believe and not believe to information on the PHW." According to their experience, some of non-smokers believe the PHW if they witnessed their relatives suffer from the disease, other participants doubt as they saw their relatives had been smoking for a long time and are still healthy. It was a surprise that suddenly there was a health warning with an image and explanation text on each cigarette package. Previously, there had been only small textual warnings on each cigarette package written "smoking can cause cancer, heart attack, impotence and pregnancy, and fetal disorders."

The PHWs' key message was informing the danger of smoking targeting smokers. Non-smoker participants considered the government as half-hearted at controlling smoking. The participants suggest that the government should not only give information to ensure smokers to quit but also more assertive actions such as "increase the cigarette price" or more extreme suggestions such as "close the manufactures." The government can do those actions, but they did not do 
Table 4: Categories and example statements of emotional response, cognitive, and conative domains among non-smokers

\begin{tabular}{|c|c|}
\hline Themes and categories & Example statements \\
\hline \multirow{2}{*}{\multicolumn{2}{|c|}{$\begin{array}{l}\text { Emotional response } \\
\text { Feel Grateful }\end{array}$}} \\
\hline Feel Grateful & \\
\hline a. Initially disgusted & $\begin{array}{l}\text { "This is really a terrible picture, this is precisely...people see } \\
\text { this, terrible and disgusting...like that." (A man, } 38 \text { years) }\end{array}$ \\
\hline \multirow[t]{2}{*}{$\begin{array}{l}\text { b. Sense of relieved but } \\
\text { pity for smokers }\end{array}$} & $\begin{array}{l}\text { "But I often feel wow I'm lucky I didn't smoke, that's often } \\
\text { arise when I look at those pictures." (A man, } 38 \text { years) }\end{array}$ \\
\hline & $\begin{array}{l}\text { "Seeing picture like this, I concerned too; I concerned for } \\
\text { those smokers should not smoke too much or stop smoke } \\
\text { if possible because smoking is harmful to one's own health } \\
\text { (while looking at the PHW of oral cancer)." (A man, } 52 \text { years) }\end{array}$ \\
\hline \multirow[t]{2}{*}{ c. Familiar with PHW } & "Yes I feel like that (disgusted) at the first time (saw the \\
\hline & $\begin{array}{l}\text { PHWs), after some time I saw it, I was indifferent, the } \\
\text { important thing I am not (at risk), just at the } 1^{\text {st }} \text { time yea...I } \\
\text { surprised wow that smoking has this effect (diseases)...yea } \\
\text { there was a feeling like that bro." (A man, } 38 \text { years) }\end{array}$ \\
\hline $\begin{array}{l}\text { d. Triggered by the } \\
\text { disgusting aspect of } \\
\text { the image: color, cut }\end{array}$ & $\begin{array}{l}\text { "Yes... the lungs are like these with blister as well (pointing } \\
\text { at PHW of pulmonary cancer), those who see it must be } \\
\text { uncomfortable seeing it." (A man, } 18 \text { years) }\end{array}$ \\
\hline \multicolumn{2}{|r|}{ a } \\
\hline \multicolumn{2}{|l|}{ Doubtful } \\
\hline \multirow[t]{2}{*}{$\begin{array}{l}\text { a. Content: between } \\
\text { believe and not } \\
\text { believe the PHW }\end{array}$} & $\begin{array}{l}\text { "I only need evidence if it is correct or false, if I prove with my } \\
\text { own eyes seeing those smokers, for example, lips cancer, what } \\
\text { cancer on their lips, the fact their lips are still like that (ordinary } \\
\text { lips with no cancer) that is what I mean." (A male, } 47 \text { years) }\end{array}$ \\
\hline & $\begin{array}{l}\text { "He is a heavy smoker, he prefers not to eat than not to } \\
\text { smoke, now the impact he is really thin, my brother-in-law... } \\
\text { if I see the impact, it is not good, yea smoking is not good.." } \\
\text { (A man, } 38 \text { years) }\end{array}$ \\
\hline $\begin{array}{l}\text { b. Target: Messages are } \\
\text { primarily for smokers }\end{array}$ & $\begin{array}{l}\text { "Maybe the government aims for those smokers to think oh } \\
\text { yea if I smoke for a long time I could be like this, oh yea if I } \\
\text { smoke for a long time I can become like this, right?" (A man, } \\
35 \text { years) }\end{array}$ \\
\hline $\begin{array}{l}\text { c. Aim: Should be more } \\
\text { than just informing }\end{array}$ & $\begin{array}{l}\text { "I have an idea.like this.. for cigarettes it should be written (on } \\
\text { the package) the price of cancer how many tens of million } \\
\text { rupiah... heart disease how many tens of million rupiah..I } \\
\text { believe that smokers will think if they get sick...they must pay } \\
\text { that much...because if the picture of the impact (diseases) of } \\
\text { smoking like this, it doesn't work." (A man, } 24 \text { years) }\end{array}$ \\
\hline $\begin{array}{l}\text { d. Sender: The } \\
\text { government can } \\
\text { control smoking } \\
\text { problem but doesn't } \\
\text { do it }\end{array}$ & $\begin{array}{l}\text { "So, for example, you may buy it, you may not buy it as } \\
\text { well. It means that not really what is it..the government has } \\
\text { not completely control smoking. If it is completely prohibit } \\
\text { smoking yea better to close the factories, isn't that right? Ha.. } \\
\text { ha..haa (laughing)." ( A man, } 61 \text { years) }\end{array}$ \\
\hline Conative & \\
\hline \\
\hline a. Avoid the image & $\begin{array}{l}\text { "If you see like this with your eyes it is unpleasant, just avoid } \\
\text { it, you know." (A man) }\end{array}$ \\
\hline $\begin{array}{l}\text { b. More confident stay } \\
\text { smoke free }\end{array}$ & $\begin{array}{l}\text { "In that picture, yea...the writings on that picture, for me as a } \\
\text { non-smoker I even don't think to start smoke at all." (A man, } \\
42 \text { years) }\end{array}$ \\
\hline $\begin{array}{l}\text { c. Smoker will not } \\
\text { give up }\end{array}$ & $\begin{array}{l}\text { "For those already addicted (smoking), it seems no..no..no.. } \\
\text { don't care, maybe to those who will try yea maybe like me } \\
\text { who want to try, and see like this maybe it affects me, you } \\
\text { know may be it affects." (A man, } 20 \text { years) } \\
\text { "They think (those smokers) it's hard for me to quit smoking } \\
\text { but they can live in balance ee... it means they have regular } \\
\text { bedtime and wake up time, eat regularly they can do it but not } \\
\text { stop smoking, so they wish with that regular balancing they can } \\
\text { compensate the negative effect of their smoking habit." (A man) } \\
\text { "Javanese people believe in destiny, smoker or non-smoker } \\
\text { if a non-smoker has a destiny not to reach } 90 \text { years, he is } \\
\text { certainly will die (before } 90 \text { years), they argue like that, right." } \\
\text { (A man, } 47 \text { years) }\end{array}$ \\
\hline
\end{tabular}

that because the government earns tax from cigarette business (Table 4).

\section{Conative: Accept}

Although non-smokers questioned the credibility of PHWs, they expressed their acceptance of the suggested behavior of staying smoke free as the consequence for the information on the PHWs. Nonsmoker participants accepted the warning message that smoking was dangerous and encouraged more to stay smoke free. However, the uncomfortable feeling observing the PHW on cigarette packs made them avoid those PHW, for example, by looking at those images not too long. Furthermore, the non-smoker participants argued PHW would not make smokers stop their smoking habit because of addiction to cigarettes. Non-smokers considered that smokers have tried to balance their unhealthy smoking habit with healthier habits. If smokers have tried, then they left their health and sickness affairs to God to determine as part of destiny (Table 3).

\section{Discussion}

This research is trying to explore the nature and extent of the reaction and the impact of the PHW implementation among smokers and non-smokers in Sleman District, Indonesia. This study found that PHWs raised intended negative emotional response; however, this unpleasant emotional response was wear out over time. For smokers, the message was not strong enough to defeat smoking addiction so that smokers continue to smoke and try to manage their risk of illness themselves. Among non-smokers, they accepted not to smoke and were more confident in being non-smokers. Both smokers and non-smokers thought the government are half-hearted in controlling the smoking problem. Smokers were grateful, but non-smokers were sorry for this.

\section{Smokers}

PHWs that delivered messages in nonsymbolical ways could arouse threat, especially among smokers, as we have reported separately [15]. By displaying diseased body parts showed a different color and shape from normal organs raised a threat of smoking to health. These results are in line with a research identified an effective $\mathrm{PHW}$ in Indonesia is a graphic PHW which shows diseased body parts such as images of mouth, throat, and lung cancers and not symbolic imagery as pictures of smoker with skulls or smoker with child [25], [26].

A study on the image of the smoker with child PHW found that the warning was not obvious to understand [27]. Our research showed that smokers avoid their fear of warnings by choosing symbolic images. Over time, PHW has become wear out, and no longer creates fear. We have also reported these results [16]. Similar research results in Jordan show PHWs loss its ability to evoke fear and suggest replacing it with a proven stronger PHW [28]. It is necessary to further investigate how long replacement of PHW is needed.

Smokers are worried about messages in PHW but deny and cover up fears by shifting to other issues. Smokers cover up action as reflected in the following codes: PHW is just information that cigarettes are dangerous, messages on PHWs are primarily not for smokers themselves and saying pity for the person 
on PHW. Informants claimed that PHW is "just" a government message that cigarettes are dangerous, but it is "incorrect." Smokers shift fear to other issues by assuming that the primary target of the message are other people or other smokers but not themselves, and the emergence of a sense of pity for the person on PHW. This denial and covering up attitude probably arises because the smoking habit has long been accepted as a part of everyday life and has deeply rooted in culture [29], so that warnings are something that disturbs peace and triggers confusion. Confusion arises because the government allows cigarettes as a legal commodity; on the contrary, the government threatened the consumers about the dangers of smoking. If the message about the dangers of smoking is correct, why is the government half-hearted to control smoking? Denial of the fact in the message shown by smokers' actions to avoid messages. We interpreted that even though smokers state the information are incorrect; they deeply think the possibility the messages are correct, threaten their health and even their lives. A research found avoiding PHW messages is not a defensive, but a sign of deeply thinking about the truth of the message and what further action needed [30]. This study shows that smokers hesitating the choice between fear of being threatened by diseases that may arise from smoking or fear defeating smoking addiction. However, smokers choose to keep smoking. We reported elsewhere, some smokers extremely claimed they are not afraid to die for the sake of smoking [17]. The smokers feel fortunate for the government is half-hearted in controlling smoking.

Smokers reject the suggested message to control smoking, which is not in line with a study that showed a threatening $\mathrm{PHW}$ related to the intention to quit smoking [31]. In this study, PHW using fear appeal was successful to raise perceived susceptibility of diseases threat caused by smoking. However, low self-efficacy among smokers to quit smoking and low credibility toward the messages lead to negative coping of refusing to quit smoking as explained in EPPM theory [32]. We conducted this research in the beginning of $\mathrm{PHW}$ policy implementation, so probably the smokers are still in the beginning of dynamic consideration between fear of diseases or fear of defeating smoking addiction. If smoking control actions are consistent and tightened, possibly improve the credibility of the messages and more smokers will choose to quit smoking. Therefore, government should complement the PHW implementation with some efforts to improve self-efficacy of smokers, for example, providing the quit line [33]. Further research to measure the prevalence of smoking and the dynamic of cigarette control policies is needed.

Besides, continuing smoking, smokers try to reduce their risk of suffering from disease by balancing unhealthy smoking habit with other behaviors that are healthy, such as exercise, adequate rest, and consuming a healthy diet. Smokers also practice other habits that they think are healthy, such as drinking more soda water, milk, plain water, giving a time lag between eating and smoking. This result is in line with other research in Yogyakarta, which states balancing risky behavior with behaviors that are considered healthier [34]. If they have carried efforts to manage the risk of illness, the smoker will then leave the affairs of health and sickness to God's destiny mechanism, as also mentioned on a research found a belief that sickness and death are destiny from God [34].

\section{Non-smokers}

In line with the smoker's response to PHW, the non-smoker's also feel a negative emotional state but milder. Non-smoker emotional response is disgust toward images in PHW that show a cut body and an organ color that differs from normal organs. Even though they worried about their smoking relatives, nonsmokers feel relieved because they are not smoking so they will not suffer from those smoking-related diseases. This is in line with research which states that the impact of PHW is not only for smokers but also for non-smokers [12]

Compared to smokers, the non-smokers also doubts the credibility of messages in $\mathrm{PHW}$ with a milder escalation, because they have never seen the illness of smokers around them as shown on the messages, smoking has become a way of social acceptance [35]. They also try to avoid PHW easily by getting rid of it or not paying attention to it. As previously explained, this avoidance is a signal for a deeper thought process [30], and non-smokers become more confident about staying smoker-free.

This study showed that PHW as a threatening message can induce not only fear but also the feeling of disgust, concern, and gratitude and also the intention to stay not smoking. This result is in line with evidence found that fear appeals effectively influence attitude, knowledge, and behavior to those who accept the message [36]. Theory of EPPM showed that those who did not perceive the threat of the message will not process the message further. However, our findings showed that even though nonsmokers did not perceive their susceptibility toward threat, they perceived the severity of the threat that results in greater intention to stay smoke free [21], [32].

Non-smokers think further about the message sender, the government. Non-smokers feel the government is inappropriate for not being serious in controlling smoking, even though the government has the authority to do so. The informants speculated the government's reluctant because of the economic issue of large tobacco taxation earnings. They expected the government not only threatened smokers, but should act to further help smokers. Supporting this opinion, PHW will be more effective if it not only gives appeal but also delivers a gain frame on the benefits of quitting and how to quit smoking [37]. 


\section{Implication for policy}

The government should be more assertive in controlling smoking by implementing tighter tobacco control policies to raise cigarette taxation, banning all tobacco advertisements, warn about the dangers of smoking using intensive health education, help quit smoking, protect passive smokers with smoking areas restriction, and monitor the smoking epidemic as proven to be effective policies in the FCTC [3]. Otherwise, the government gets a negative impression as negated public opinion by not seriously controlling smoking because of fear of losing tobacco taxation earnings. This concern was one of the barriers of tobacco control in Indonesia [38]. Cigarette is a promising commodity from government economic perspective [38], besides this commodity has been socially and culturally accepted in the population [29]. Those facts together with the unclear roles and responsibility are the most difficult barrier of tobacco control effort in Indonesia. Actually, the passive smokers support stronger tobacco control policies such as increasing cigarette prices, using religious approach regulation and using more effective pictorial PHW [39], [40] This study supports that PHWs are not a single strategy to control smoking and needs other strategies in combination.

People need health education to improve awareness that having more than one risk factor, such as smoking and sedentary life, will increase a person's chances of contracting NCD [41]. It does not mean balancing smoking with other health habits is good, but the best option is to quit smoking with help provided by the government [3]. The absence of support to stop smoking will affect smokers' distrust of the negative impacts of smoking and distrust of policies on smoking control programs [29].

\section{Limitation and trustworthiness}

We conducted the research location in Sleman Regency; it limits broader Indonesia. However, considering the people of Sleman come from all over Indonesia and the method of taking respondents using maximum variation sampling with detailed descriptions of respondent characters, we expect to reduce these limitations and help the transferability of the results broader [42]. Although the results confirm various other studies on $\mathrm{PHW}$ in Indonesia, in order to generalize conceptually to the country, it needs similar research in several regions.

\section{Conclusions}

The application of PHW makes smokers feel threatened, but does not make them quit smoking because of the fear of defeating cigarette dependence. Being exposed to PHW, non-smokers feel more confident to be a smoker free. Respondents claimed the government was not serious about controlling smoking, because they think that the government should not only implement PHW but also need to implement other tighter control policies.

\section{References}

1. World Health Organization. Tobacco Smoking: Prevalence of Tobacco Smoking. Geneva: World Health Organization; 2018. Available from: https://www.apps.who.int/gho/data/node.sdg.3a-viz?lang=en. [Last accessed on 2021 Jan 06]. https://doi. org/10.1787/884a981b-en

2. Rentería E, Jha P, Forman D, Soerjomataram I. The impact of cigarette smoking on life expectancy between 1980 and 2010: A global perspective. Tob Control. 2016;25(5):551-7. https://doi. org/10.1136/tobaccocontrol-2015-052265

PMid:26307052

3. World Health Organization. The WHO Framework Convention on Tobacco Control. Geneva: World Health Organization; 2003. https://www.apps.who.int/iris/bitstream/ handle/10665/42811/9241591013.pdf? sequence=1. [Last accessed on 2019 Sep 25]. https://doi.org/10.1017/ s0020782900010202

4. World Health Organization. Ministry of Health Indonesia, CDC Foundation. Global Adult Tobacco Survey: Indonesia Report 2011. Geneva: World Health Organization; 2012. Available from: https://www.who.int/tobacco/surveillance/survey/gats/ indonesia_report.pdf. [Last accessed on 2019 Sep 25]. https:// doi.org/10.26719/2015.21.6.379

5. Ministry of Health Indonesia. Regulation of The Health Minister of The Republic of Indonesia Number 28 of 2013 Concerning Imprinting of Health Warnings and Health Information on Tobacco Product Packaging. Jakarta: Kementerian Kesehatan RI; 2013.

6. Presiden Republik Indonesia (President of the Republic of Indonesia). Peraturan Pemerintah Republik Indonesia Nomor 109 Tahun 2012 Tentang Pengamanan Bahan yang Mengandung Zat Adiktif Berupa Produk Tembakau Bagi Kesehatan (Republic of Indonesia Government Regulation Number 109 Year 2012 Regarding Safeguarding Materials Containing Addictive Substances in the Form of Tobacco Products for Health); 2012. Available from: https://www.jdih.setkab.go.id/PUUdoc/173643/ PP1092012.pdf. [Last accessed on 2019 Sep 25]. https://doi. org/10.31219/osf.io/xtdba

7. Brewer NT, Hall MG, Noar SM, Parada H, Stein-Seroussi A Bach LE, et al. Effect of pictorial cigarette pack warnings on changes in smoking behavior: A randomized clinical trial. JAMA Intern Med. 2016;176(7):905-12. https://doi.org/10.1001/ jamainternmed.2016.2621

PMid:27273839

8. Kale D, Gilbert HM, Sutton S. Are predictors of making a quit attempt the same as predictors of 3-month abstinence from smoking? Findings from a sample of smokers recruited for a study of computer-tailored smoking cessation advice in primary care. Addiction. 2015;110(10):1653-64. https://doi.org/10.1111/ add. 12972

PMid:25939254

9. Layoun N, Hallit S, Waked M, Bacha ZA, Godin I, Leveque A, et al. Predictors of past quit attempts and duration of abstinence among cigarette smokers. J Epidemiol Glob Health. 2017;7(3):199-206. https://doi.org/10.1016/j.jegh.2017.06.003 PMid:28756830 
10. Zhao L, Song Y, Xiao L, Palipudi K, Asma S. Factors influencing quit attempts among male daily smokers in China. Prev Med. 2015;81:361-6. https://doi.org/10.1016/j.ypmed.2015.09.020 PMid:26441296

11. Alkaff FF, Sukmajaya WP, Armadani A, Moksidy RC, Salma RS, Rifqi $\mathrm{K}$, et al. The effectivity of pictorial health warning to motivate smoking cessation in rural area: A study from Losari village, Indonesia. J Educ Health Promot. 2020;9:67. PMid:32490002

12. Ratih SP, Susanna D. Perceived effectiveness of pictorial health warnings on changes in smoking behaviour in Asia: A literature review. BMC Public Health. 2018;18(1):1165. https://doi. org/10.1186/s12889-018-6072-7

13. Bhat A, Shilpashree KB, Krishnamurthy A, Manjunath $C$, Shwetha R, Madhusudhan S. Adolescent's perception about the introduction of new cigarette packaging and plain packaging of cigarette packs: A qualitative study. Indian J Community Med. 2018;43(Suppl 1):S47-51. https://doi.org/10.4103/ijcm. ijcm_97_18 PMid:30686875

14. Elton-Marshall T, Wijesingha R, Kennedy RD, Hammond D. Disparities in knowledge about the health effects of smoking among adolescents following the release of new pictorial health warning labels. Prev Med. 2018;111:358-65. https://doi. org/10.1016/j.ypmed.2017.11.025 PMid:29195760

15. Baiquni F, Dewi FST, Widyatama R. Eksplorasi ancaman peringatan kesehatan bergambar pada kemasan rokok (Explore the threat of pictorial health warnings on cigarette packaging). Berita Kedokteran Masyarakat. 2016;32(7):223-30. https://doi. org/10.22146/bkm.11617

16. Mappaghau RN, Dewi FS, Triratnawati A. Respon Masyarakat Terhadap Peringatan Bergambar Pada Kemasan Rokok di Wilayah Perkotaan Kabupaten Sleman, Yogyakarta (Community's Response toward Pictorial Health Warning on the Cigarette Package in the Urban Area of Sleman District, Yogyakarta). [Unpublished Master's Thesis]. In Press; 2016. https://doi.org/10.31934/promotif.v7i1.22

17. Urrahman D, Dewi FS, Hamsyah F. Orang Desa tidak takut mati": Studi kualitatif koping masyarakat terhadap peringatan bergambar pada kemasan rokok dengan pendekatan grounded theory. ("Village people are not afraid to die": A qualitative study of community coping to pictorial warnings on cigarette packages using a grounded theory approach). Berita Kedokteran Masyarakat. 2016;32(8):263-72. https://doi.org/10.22146/ bkm.8699

18. Central Bureau of Statistics (Badan Pusat Statistik). Kabupaten Sleman Dalam Angka 2019 (Sleman Regency in Figures 2019); 2019. Available from: https://www.slemankab.bps.go.id/ publication/2019/08/16/c400805c8dee98a3d701ea33/ kabupaten-sleman-dalam-angka-2019.html. [Last accessed on 2020 Aug 05]. https://doi.org/10.46807/aspirasi.v10i2.1386

19. Creswell JW, Clark VL. Designing Mixed Methods Research. California, USA: SAGE Publications Inc.; 2007.

20. Creswell J. Qualitative Inquiry and Research Design: Choosing among Five Approaches. $4^{\text {th }}$ ed. California, USA: SAGE Publication Inc.; 2017.

21. Witte K, Allen M. A meta-analysis of fear appeals: Implications for effective public health campaigns. Health Educ Behav. 2000;27(5):591-615. https://doi. org/10.1177/109019810002700506

PMid:11009129

22. Graneheim UH, Lundman B. Qualitative content analysis in nursing research: Concepts, procedures and measures to achieve trustworthiness. Nurse Educ Today. 2004;24(2):105-12. https://doi.org/10.1016/j.nedt.2003.10.001

\section{PMid: 14769454}

23. ICT Services and System Development and Division of Epidemiology and Global Health. OpenCode 4.03; 2013. Available from: http://www.phmed.umu.se/english/units/ epidemiology/research/open-code. [Last accessed on 2019 Sep 25].

24. O'Brien BC, Harris IB, Beckman TJ, Reed DA, Cook DA Standards for reporting qualitative research: A synthesis of recommendations. Acad Med. 2014;89(9):1245-51. https://doi. org/10.1097/acm.0000000000000388 PMid:24979285

25. Anshari D. Effectiveness of Pictorial Health Warning Labels for Indonesia's Cigarette Packages. Columbia: University of South Carolina; 2017.

26. Sutton JA, Yang S, Cappella JN. Perceived effectiveness of objective features of pictorial warning messages. Tob Control. 2019;28(e1):e24-30. https://doi.org/10.1136/ tobaccocontrol-2018-054488 PMid:30361323

27. Samosir DS, Priyatna CC, Hafiar H. Makna pictorial health warning pada kemasan rokok dalam mengomunikasikan pesan bahaya merokok. (The meaning of pictorial health warning on cigarette package in communicating messages of smoking hazard). J Nomosleca. 2019;5(1):2750. https://doi. org/10.26905/nomosleca.v5i1.2750

28. Bader RK, Shihab RA, Al-Rimawi DH, Hawari FI. Informing tobacco control policy in Jordan: Assessing the effectiveness of pictorial warning labels on cigarette packs. BMC Public Health. 2017;18(1):84. https://doi.org/10.1186/s12889-017-4642-8

29. Nichter M, Padmawati S, Danardono $\mathrm{M}, \mathrm{Ng} \mathrm{N}$, Prabandari $Y$ Nichter M. Reading culture from tobacco advertisements in Indonesia. Tob Control. 2009;18(2):98-107. https://doi. org/10.1136/tc.2008.025809

PMid: 19033331

30. Hall MG, Mendel JR, Noar SM, Brewer NT. Why smokers avoid cigarette pack risk messages: Two randomized clinical trials in the United States. Soc Sci Med. 2018;213:165-72. https://doi. org/10.1016/j.socscimed.2018.07.049 PMid:30096636

31. Thrasher JF, Swayampakala K, Borland R, Nagelhout G, Yong $\mathrm{HH}$, Hammond D, et al. Influences of self-efficacy, response efficacy, and reactance on responses to cigarette health warnings: A longitudinal study of adult smokers in Australia and Canada. Health Commun. 2016;31(12):1517-26. https://doi.org/ 10.1080/10410236.2015.1089456

PMid:27135826

32. Popova L. The extended parallel process model: Illuminating the gaps in research. Health Educ Behav. 2012;39(4):455-73. https://doi.org/10.1177/1090198111418108 PMid:22002250

33. Elshatarat RA, Yacoub MI, Khraim FM, Saleh ZT, Afaneh TR. Self-efficacy in treating tobacco use: A review article. Proc Singapore Healthc. 2016;25(4):243-8. https://doi. org/10.1177/2010105816667137

34. Dewi FS, Weinehall L, Ohman A. Maintaining balance and harmony: Javanese perceptions of health and cardiovascular disease. Glob Health Action. 2010;3:4660. https://doi. org/10.3402/gha.v3i0.4660

PMid:20411051

35. Subramaniam SV, Istiqomah AN, Fadlyana E. Peer pressure and smoking behavior in elementary school students. Althea Med J. 2017;4(1):1-5. https://doi.org/10.15850/amj.v4n1.1012

36. Tannenbaum MB, Hepler J, Zimmerman RS, Saul L, Jacobs S, Wilson $\mathrm{K}$, et al. Appealing to fear: A meta-analysis of fear appeal effectiveness and theories. Psychol Bull. 2015;141(6):1178-204. 
https://doi.org/10.1037/a0039729

PMid:26501228

37. Strahan EJ, White K, Fong GT, Fabrigar LR, Zanna MP, Cameron R. Enhancing the effectiveness of tobacco package warning labels: A social psychological perspective. Tob Control. 2002;11(3):183-90. https://doi.org/10.1136/tc.11.3.183 PMid:12198266

38. Astuti PA, Assunta M, Freeman B. Why is tobacco control progress in Indonesia stalled? A qualitative analysis of interviews with tobacco control experts. BMC Public Health. 2020;20(1):527. https://doi.org/10.1186/s12889-020-08640-6

39. Nurhasana R, Ratih SP, Djaja K, Hartono RK, Dartanto T. Passive smokers' support for stronger tobacco control in Indonesia. Int J Environ Res Public Health. 2020;17(6):1942. https://doi.org/10.3390/ijerph17061942

PMid:32188091

40. Rosser A. Contesting tobacco-control policy in Indonesia Critical Asian Studies. 2015;47(1):69-93. https://doi.org/10.108 0/14672715.2015.997083

41. Peters R, Ee N, Peters J, Beckett N, Booth A, Rockwood K, et al. Common risk factors for major noncommunicable disease, a systematic overview of reviews and commentary: The implied potential for targeted risk reduction. Ther Adv Chronic Dis. 2019;10:2040622319880392. https://doi. org/10.1177/2040622319880392

PMid:31662837

42. Sandelowski M. Using qualitative research. Qual Health Res. 2004;14(10):1366-86. 